\title{
Non-Traumatic Pseudocyst of the Spleen: A Case Report
}

\author{
Dalağın Travmatik Olmayan Psödokisti: Bir Olgu Sunumu
}

\author{
Metin Șenol, Hakan Özdemir, İbrahim Tayfun Șahiner, Zehra Ünal Özdemir \\ General Surgery Clinics, I. Şevki Atasagun Nevşehir State Hospital, Nevşehir Turkey
}

\begin{abstract}
Splenic cysts are seen rarely in surgical practice and most of them are parasitic cysts (hydatid cyst). Non-parasitic cysts are classified as true and false cysts (pseudocyst). Pseudocysts are usually secondary to trauma or hemorrhage of spleen. They are believed to be the final stage of organization of an intra-splenic hematoma and are hardly differentiated from hydatid cyst preoperatively. Surgery is the treatment of choice in symptomatic cysts, particularly with a diameter of larger than $5 \mathrm{~cm}$. In this paper, we present a $12 \mathrm{~cm}$ splenic cyst of a 32-year-old male. Pathological examination after total splenectomy via laparotomy revealed splenic pseudocyst. However, the medical history of the patient was unremarkable and there wasn't any history of trauma.
\end{abstract}

Key words: pseudocyst; spleen; splenectomy

\section{ÖZET}

Cerrahi pratikte dalak kistleri nadir görülürler ve çoğu da parazitik kistlerdir (hidatit kist). Parazitik olmayan kistler gerçek ve yalancı kistler (psödokist) olarak sınıflandırılırlar. Psödokistler genellikle dalaktaki travma ya da kanamaya ikincildirler. Dalaktaki hematomun organizasyonunun son basamağı olduklarına inanılırlar ve operasyon öncesi hidatit kistten güçlükle ayırt edilebilirler. Belirti veren, özellikle $5 \mathrm{~cm}$ 'den büyük kistlerin tedavi seçeneği cerrahidir. Bu yazıda, 32 yașındaki bir erkekteki 12 cm'lik dalak kistini sunuyoruz. Laparotomi ile total splenektomi sonrası yapılan patolojik incelemede dalak psödokisti tanısı konuldu. Ancak, hastanın tıbbi geçmișinde belirgin bir özellik ve travma öyküsü yoktu.

Anahtar kelimeler: psödokist; dalak; splenektomi

Uzm. Dr. Metin Senol, İ. Sevki Atasagun Nevşehir Devlet Hastanesi, Genel Cerrahi Kliniği, Nevşehir, Türkiye, Tel.03842285050Email.drmetinsenol@gmail.com Geliş Taribi: 31.10.2013 • Kabul Taribi: 08.02.2014

\section{Introduction}

Splenic cysts are divided into two groups: primary (true) and secondary (false). Primary cysts have epithelial or endothelial lining which is absent in secondary cysts. Primary splenic cysts are classified as parasitic or non-parasitic and most of them are parasitic cysts resulted secondary to Echinococcus granulosus infestation. Non-parasitic cysts may have epithelial covers as epidermoid, dermoid and mesothelial cysts have, or endothelial covers as hemangiomas and lymphangiomas have. Epidermoid cysts account for $90 \%$ of primary non-parasitic cysts. Secondary cysts, also named as pseudocyst, usually develop after an abdominal trauma, and less frequently as a result of mononucleosis, tuberculosis or malaria ${ }^{1,2}$.

False cysts are also called as pseudocyst because they do not have capsules. Trauma is the most common etiological factor. They are believed to be the final stage of organization of an intra-splenic hematoma. In this paper, we present a $12 \mathrm{~cm}$ splenic cyst of a 32-year-old male. Pathological examination after total splenectomy via laparotomy revealed splenic pseudocyst. However, the medical history of the patient was unremarkable and there wasn't any history of trauma.

\section{Case Report}

A 32-year-old man complaining of a left sided abdominal pain was admitted to our clinic. He has had abdominal distension, fullness in the epigastrium, nausea and vomiting for the last few months. Physical examination revealed a mass in the left upper quadrant of the abdomen. The medical and surgical histories were 
unremarkable and there was not any history of trauma or parasitic infection.

Laboratory tests including complete blood count, liver and kidney function tests revealed measurements within normal reference ranges. A calcified mass was seen in the spleen during the abdominal plain X-ray examination (Figure 1), thus we ordered a computerized tomography (CT) to examine the spleen. CT scan revealed a $12 \mathrm{~cm}$ cystic mass in spleen with peripheral calcifications compatible with a hydatid cyst (Figure 2). However, serologic testing for Echinococcus was negative.

Since the cyst was larger than $5 \mathrm{~cm}$ and the patient had worsening of the symptoms, we preferred surgical treatment. Preoperatively, the patient had a Pneumococcus vaccine.

During intra abdominal exploration via median vertical incision, we saw a very large cyst, almost entirely covered by splenic parenchyma, and thus we preferred total splenectomy instead of perforation or aspiration of the cyst. Postoperative follow up was uneventful. Oral nutrition was started on postoperative day one and the patient was discharged on postoperative day three.

Postoperative pathologic examination revealed a 12 $\mathrm{cm}$ splenic pseudocyst with a peripherally calcified wall lacking epithelial lining. The cyst was surrounded by a thin splenic parenchymal layer. The diameters of the splenectomy material were measured as $18 \times 16 \times 12 \mathrm{~cm}$ (Figure 3).

\section{Discussion}

Splenic cysts are rarely seen in daily surgical practice. They are commonly seen in children and young adults. Szczepanik et al. reported that the number of splenic cysts constituted 11 (3.8\%) of all 290 patients

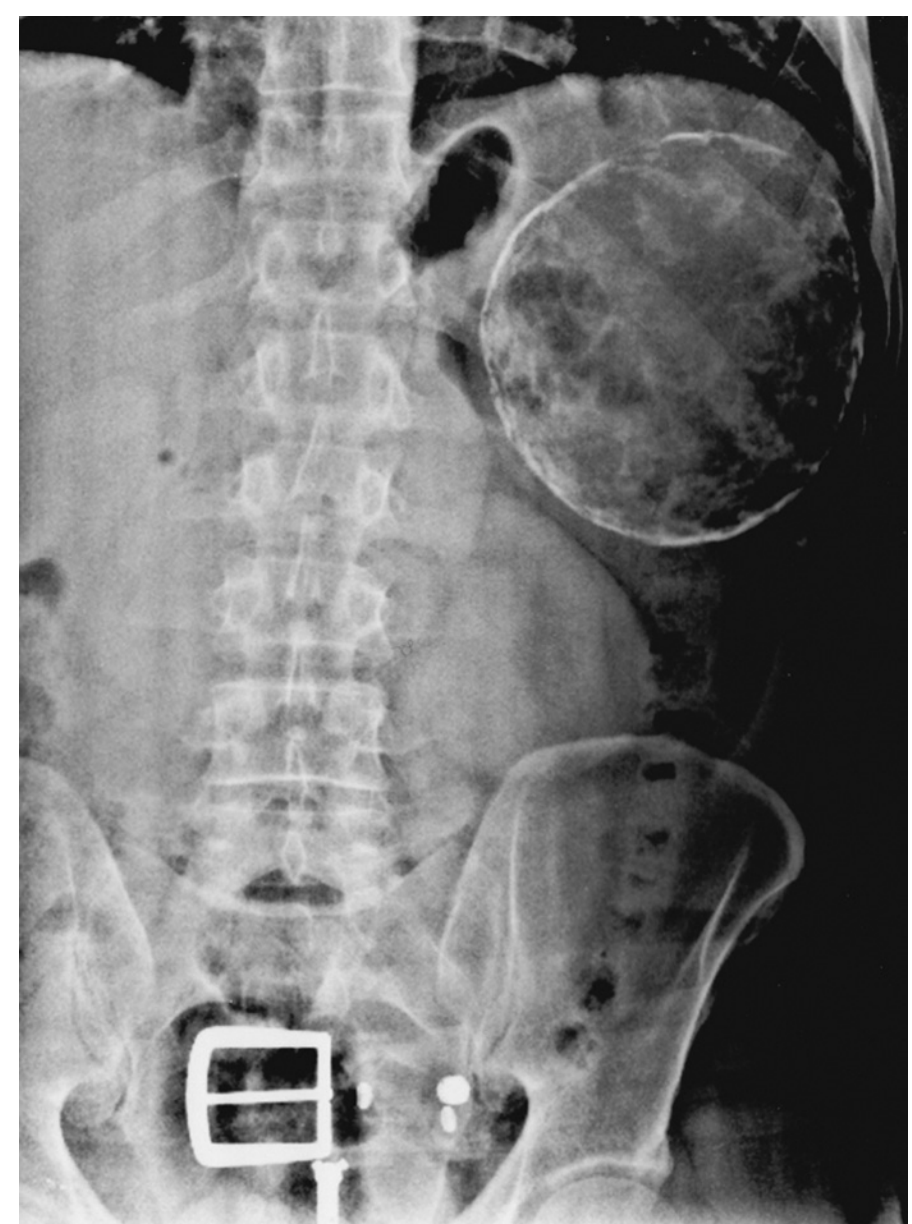

Figure 1. Plain X-ray examination of spleen demonstrating a calcified mass. 


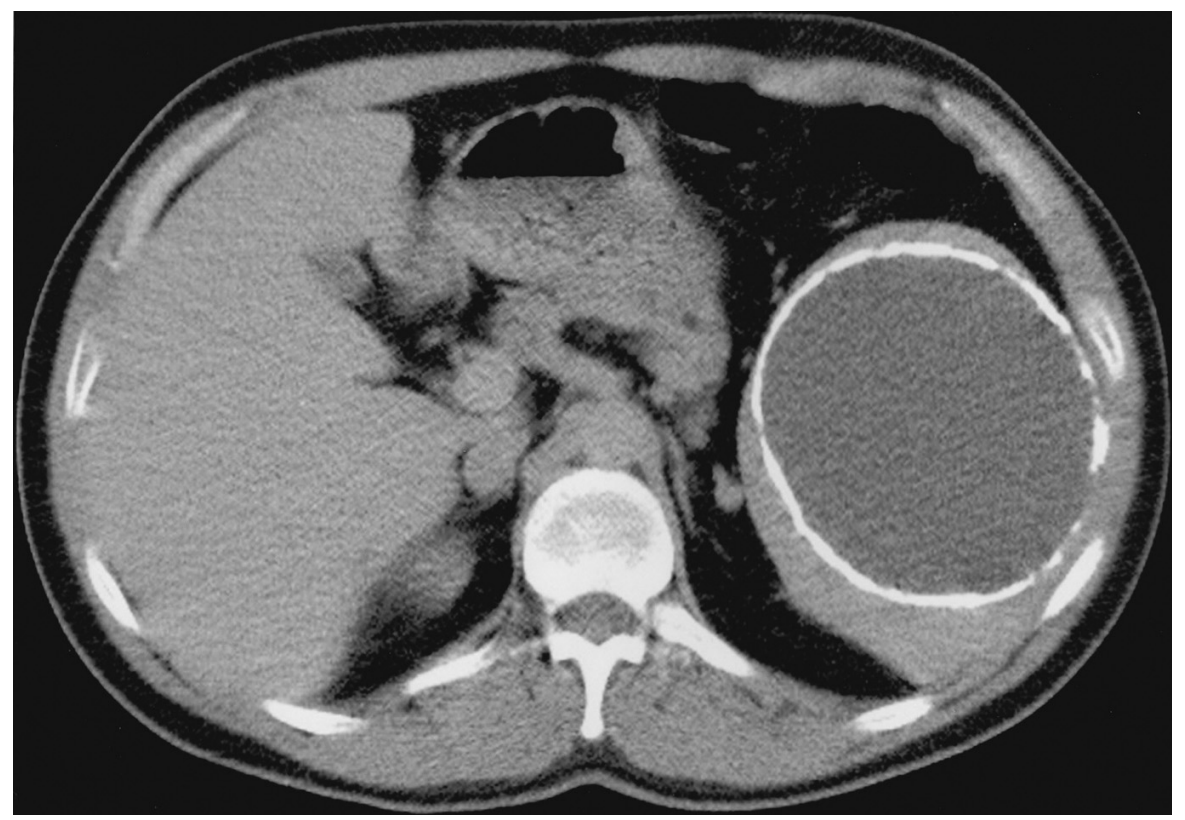

Figure 2. Abdominal CT scan demonstrating a $12 \mathrm{~cm}$ cystic mass with peripheral calcifications.

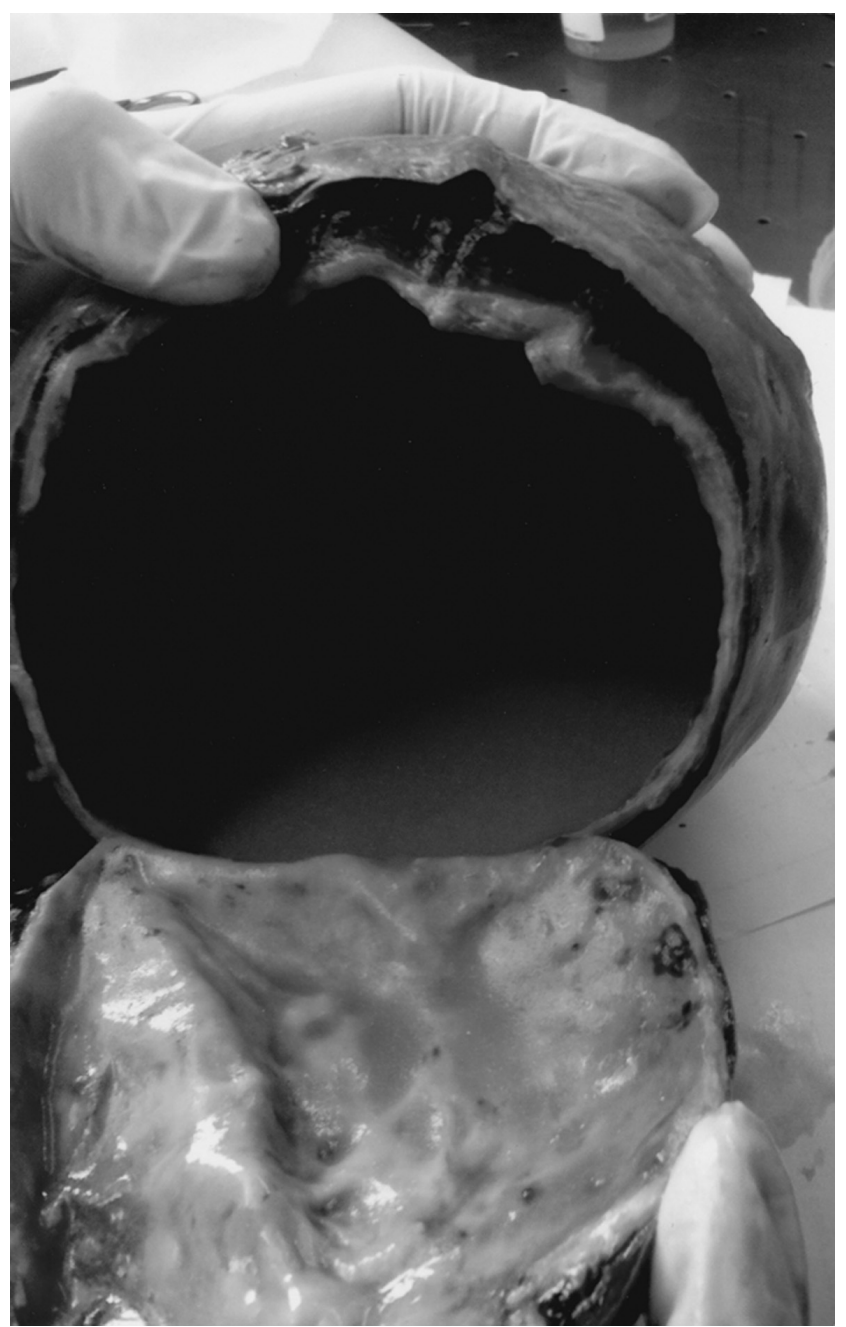

Figure 3. Splenectomy specimen including the pseudocyst. 
subjected to splenectomy during the study period of 4 years ${ }^{3}$. Management of the splenic cyst depends on threefold questioning; What is the nature of the cyst? Should we operate? And which operation will we perform? ${ }^{4}$.

Splenic cysts are more often diagnosed nowadays, probably due to the increased use of abdominal ultrasound and CT examinations. However, it's difficult to distinguish true and false cysts. Most of the splenic cysts are asymptomatic until they reach significant sizes. Large cysts may cause left sided upper abdominal pain and other symptoms of space occupation, secondary to the enlarging cystic mass within the abdominal cavity 5 . Symptomatic cysts and cysts larger than $5 \mathrm{~cm}$, whether symptomatic or not, are generally managed surgically.

Pseudocysts comprise about three-quarters of all non-parasitic cysts of spleen. They are secondary to trauma, infection or infarction. Most are asymptomatic and solitary. They can reach large sizes and contain as much as three liters of dark turbid fluid and are believed to be the final stage of organization of an intra-splenic hematoma. The fibrous capsule often exhibits a chronic inflammatory reaction and contains organized blood clots, with old blood pigment and precipitates of calcium. Macroscopically, they may contain internal debris. Microscopically, these cysts are composed of dense fibrous tissue, often calcified, with no epithelial lining ${ }^{2,6}$.

On plain films of the abdomen, plaque-like calcification is uncommon within true cysts, however it is seen in up to one-quarter of pseudo cysts. CT demonstrates the trabeculations, septations or calcifications of the cyst wall better than the ultrasound can. The diagnosis of a false cyst should be favored, if there is a clear history of trauma, hematoma elsewhere in the spleen, or if the cyst wall is calcified. The differential diagnosis includes echinococcal cyst (often has multiple septations), large solitary abscess or hematoma, or cystic neoplasm of spleen (hamartoma, hemangioma or lymphangioma $)^{7}$.

In distinctive diagnosis of splenic cystic masses, hydatid cysts should rank among first especially in endemic regions, like Turkey. The treatment choice of a splenic hydatid cyst is surgery. Operative approach varies depending on the patient's age, his/her additional systemic diseases, and the location, number and size of the cysts $^{8}$. In our case, the subclass of the cyst was not dem- onstrated accurately preoperatively, thus we preferred to perform a total splenectomy.

Various operative management options for non-parasitic splenic cysts including total splenectomy, partial splenectomy, percutaneous drainage, marsupialization of the cyst and partial cystectomy (fenestration, unroofing) are available. Characteristics of the patients and their cysts contribute in selecting the appropriate management option ${ }^{1}$.

Total splenectomy is still the most preferred surgical procedure used during the management of splenic cysts. However in recent years, the number of surgeons preferring laparoscopic approach is increasing. Total splenectomy performed laparoscopically or open is inevitable in cases where cyst is very large, located in the splenic hilum, covered completely by the splenic parenchyma (intrasplenic cyst), or if there are multiple cysts 5 . Our patient had a cyst located in the splenic hilum and covered entirely by splenic parenchyma. In addition, we could not rule out hydatid cyst.

Awareness of the importance of immunological function of spleen and the potential threat of severe post splenectomy complications have led to the development of splenic parenchyma-preserving surgical procedures. Partial splenectomy is a safe and effective operative procedure used in the management of nonparasitic splenic cysts. It ensures complete cyst removal, prevents cyst recurrence, and preserves the splenic functions ${ }^{3}$. It may be preferred in cases where the cysts are located in splenic poles.

The laparoscopic management of splenic cysts has all advantages unique to laparoscopic surgery including less pain, smaller incision, shorter hospitalization and earlier return to work. Although laparoscopic approach is a minimally invasive technique, it may not provide adequate treatment. The recurrence rates are higher, if large amounts of cyst wall are not removed. The cyst location is the most important factor for performing laparoscopic spleen preserving surgery. Superficial and non-parasitic splenic cysts are better candidates for laparoscopic approach ${ }^{9,10}$.

In conclusion, splenic cysts should be managed surgically, if they are symptomatic or if their diameters are larger than $5 \mathrm{~cm}$. If the presence of a parasitic cyst can't be ruled out preoperatively, total splenectomy is the treatment of choice, particularly in large cysts entirely covered by splenic parenchyma or located in the splenic hilum. 


\section{References}

1. Karfis EA, Roustanis E, Tsimoyiannis EC. Surgical management of nonparasitic splenic cysts. JSLS 2009;13:207-12.

2. Schlittler LA, Dallagasperina VW. Non-parasitic splenic cysts. Rev Col Bras Cir 2010;37:442-6.

3. Szczepanik AB, Meissner AJ. Partial splenectomy in the management of nonparasitic splenic cysts. World J Surg 2009;33:852-6.

4. Cissé M, Konaté I, Ka O. Giant splenic pseudocyst, a rare aetiology of abdominal tumor: a case report. Cases J 2010;3:16.

5. Macheras A, Misiakos EP, Liakakos T. Non-parasitic splenic cysts: a report of three cases. World J Gastroenterol 2005;11:6884-7.
6. Sinha PS, Stoker TA, Aston NO. Traumatic pseudocyst of the spleen. J R Soc Med 1999;92:450-2.

7. Dachman AH, Ros PR, Murari PJ. Nonparasitic splenic cysts: a report of 52 cases with radiologic-pathologic correlation. AJR Am J Roentgenol 1986;147:537-42.

8. Özdogan M, Baykal A, Keksek M. Hydatid cyst of the spleen: treatment options. Int Surg 2001;86:122-6.

9. Matsutani T, Uchida E, Yokoyama T. Laparoscopic unroofing of a large pseudocyst of the spleen: report of a case. J Nippon Med Sch 2009;76:319-22.

10. Fisher JC, Gurung B, Cowles RA. Recurrence after laparoscopic excision of nonparasitic splenic cysts. J Pediatr Surg 2008;43:1644-8. 